\title{
Quantum Learning Model as a Solution of the Tolerance and Independence Problems of Training Participants
}

\author{
Lusy Setiyowati and Iip Saripah
}

\begin{abstract}
Recently, many cases were driven by tolerance and independence inadequacy. Can quantum learning model be a solution to solve this problem? Therefore, this research was conducted to determine the correlation between quantum learning model with tolerance and independence. One of which is to complement the requirement of automotive training in UPT-PK Jember. This research engaged correlation technique with quantitative approach. That was analyzed by Rank Spearman formula. The research results indicated a significant positive relationship between quantum learning model with tolerance and independence of training participants. This was proved by the results of analysis data obtained using the $r$ of value each is 0,708 and 0,746 with a $95 \%$ confidence level. It can be implied that quantum learning model at UPT-PK or Technical Implementation Unit-Work Training Jember, Indonesia delivers tolerance rate of automotive training participants by $50 \%$ and contributed to the independence by $56 \%$.
\end{abstract}

Index Terms-Quantum learning model, tolerance, independence.

\section{INTRODUCTION}

Tolerance is an open attitude that drives someone to be able to appreciate and respect the diversity in order to gain a balanced life, so that a tolerant considers diversity as a positive opportunity to synergies towards a better [1]. Tolerance generally means an attitude that is willing to be tolerant in the form of opinions, viewpoints, customs, beliefs and behavior of others that are contrast compared to their private belief [2]. Without tolerance, there will be various conflicts, conflict can also affect the tolerance amongst groups [3]. This can be seen from several cases in Indonesia, such as Sampit confrontation (between Madura and Dayak tribe), in Aceh (GAM-GoI), in Poso rioting among religions [4]. Those conflicts seemed to prove that a sense of community as a whole has been reduced. This indicates that people has experienced a shift in behavior or morals toward the negative side, particularly the tolerance aspect towards others. High population density also requires a high level of tolerance [5]. The condition implies that tolerance is a significant issue to be absorbed by everyone. Tolerance is important for humans to cooperate in their social life [6]. The appearance of mutual appreciation attitude will establish a good relationship among each other. However, this

Manuscript received October 24, 2017; revised May 21, 2018. This work was supported in part by the LPDP Ministry of Finance of Republic of Indonesia. We are grateful to UPT-PK or Technical Implementation Unit-Work Training Jember, Indonesia as a place data collection.

The authors are with Faculty of Education, Universitas Pendidikan Indonesia, Indonesia (e-mail: lusy@ student.upi.edu). relationship does not expect to generate excessive dependency which makes one dependent. According to Agnyal [7], independence is a tendency to achieve something, to overcome something, to act effectively towards the environment, to plan and actualize their expectations. The characteristics of independence in learning according to Sardiman [8], include: obtaining their own will to argue, act and behave, obtain a motivation and strategy in achieving learning objectives, creativity and initiative thoughts and action.

Thus, someone who is considered independent able to determine what the best for him/her self. It would encourage a person to be more adaptive [9]. The improvement of adaptive capabilities enables to create autonomous employment opportunities. Therefore, the nature of independence needs to be fostered, so one does not depend on others' decision, yet he able to consider the best for himself.

Based on the explanation mentioned above, it can be seen that tolerance and independence is essential for a person, considering the number of criminal cases as a result of the disparity amongst individuals. In order to improve tolerance may perform through teaching and adjustment [10]. Thus, tolerance and independence can be developed through a process of learning and training with adequate materials and models. Training is an activity to improve knowledge, skills and attitudes through learning experiences to achieve effectiveness outcomes [11]. Therefore, training as one of non-formal school institutions should play an effective role regarding tolerance and independence development of children.

One of the models used in training and appropriate to increase tolerance and independence is quantum learning model. A quantum learning model improves cognitive, affective, and psychomotor if it is implemented effectively [12]. In the sense of quantum learning, there is modifying various interactions that occur in learning activities. Those changes are made to guide the learning process effectively and efficiently. So, engaging quantum learning model interaction between trainer and training participants emerges close relationship and learning activities can be more enjoyable [13].

Thus, quantum learning is an instructional model to improve knowledge, attitudes, skills and values that lead to a person's behavior turns to be better, through implementation of training which take into account about internal and external conditions, as well as learning outcomes, hence learning process runs effective and efficient through interactions in learning activities. The model is applied using several indicators [14] include: 


\section{1) AMBAK strength,}

AMBAK (What is the benefit to me?) is a person's motivation once after understands the benefits of learning.

2) Comfortable Learning Environment,

The learning environment is the venue for learning that has an impact upon learning outcomes. Therefore, the learning environment must provide a good atmosphere as needed to learn.

\section{3) Nurturing Champion Attitude,}

The champion attitude is a positive attitude regarding acceptance in defining the success that cannot be achieved, without failure. This is important nurtured within a person, in order to admit reality and more eager to involve in the learning process.

4) Learning Styles,

Learning style is an effort to grasp the learning material. Learning styles may affect learning outcomes if not applied properly according to the needs. Learning styles are classified into three forms, including: visual, auditory, and kinesthetic.

5) Writing Habituate,

One way can be employed to recall the knowledge in a learning process is writing.

6) Reading Habituate,

Reading is an effort to intensify knowledge through print media. By reading accustom then someone is trained to understand the essence of the passage quickly.

7) Creative Thinking

Someone who thinks creatively will be able to create ideas, get to know the possible alternatives, dare to try new things and discover new things.

\section{METHOD}

This research engaged quantitative approach, namely documentation, observation, and questionnaire process that was analyzed with Rank Spearman formula. This research was conducted for five months at UPT-PK Jember, Indonesia All participants in the automotive vocational were only nine. The address of the participants is:

TABLE I: LIST OF PARTICIPANTS ADRESS

\begin{tabular}{cl}
$\begin{array}{c}\text { Respondents } \\
\text { Number }\end{array}$ & \multicolumn{1}{c}{ Adress } \\
\hline 1. & Mandaran I, Puger, Jember, Indonesia \\
2. & Klayu, RT.01, RW.01, Mayang, Jember, Indonesia \\
3. & Ambulu, Jember, Indonesia \\
4. & Sidomulyo, Silo, Jember \\
5. & Bregoh Sumberjo, district. Ambulu, Jember, Indonesia \\
6. & Sumberwaru village, district. Sukowono, Jember, \\
7. & Indonesia \\
8. & He did not fill in the address in the questionnaire \\
9. & He did not fill in the address in the questionnaire \\
\hline \hline
\end{tabular}

According to the table above, the sub vocational trainees motorcycle of self-financing program were male and Muslim, but they originated from different background and region. They're aged between 15-18 years old and graduated from junior and senior high school. Since the number of trainees was a few, then all participants of the training were respondents in this study. Through collecting primary data process using questionnaires distributed to participants. Each submission was assessed using a Likert scale from Strongly Agree (SS) with a score of 5 to Strongly Disagree (STS) with a score of 1 . Once the entire statement items were completed, researchers re-collected the questionnaire to perform scoring, tabulating, editing and further analysis of the data by the Rank Spearman correlation formula.

\section{Result AND Discussion}

UPT-PK or Technical Implementation Unit - Work Training is an institution to manage job training which is located at Basuki Rahmat street, Jember Indonesia. This institution aims to support skills improvement, production services which enable people to find job and to be a more independent figure. Associated to these objectives, the institute conducts various job training programs managed by 42 employees. One of which is work training programs of automotive training sub vocational motorcycles. This training was established to consider the number of motorcycle users in Indonesia, thus requires more technicians in the field of motorcycles. Therefore, this automotive training has a great goal to deliver skilled motorcycle junior technicians, and able to meet the needs of the community to repair and maintenance upon motorcycles.

Based on observation results conducted, automotive training sub vocational motorcycle in UPT-PK Jember, Indonesia were joined by nine trainees. They have different backgrounds. In terms of age, they are between 15-18 years old, with a background of junior and senior high school education.

The process of applying quantum learning model during motorcycle automotive vocational training, namely:

1) Explanation of Training Benefits

The training was conducted on the basis of participants' interests to participate in the event. Participants are well aware regarding the purpose of the training hence most participants have already noticed the benefits of this training as the reason why they participate in motorcycle vocational automotive training.

2) Environmental Learning of Training Participant

The trainees obtain facility in the form of comfortable learning environment and relates to their learning needs. Classrooms are divided into three main sections. The first part is a classroom with layouts, whiteboards and seating for the trainees. The second part is a practical workshop equipped with practice media, such as: motorcycle, ring lock, wrench, and keys schok, screwdriver, pliers, magnet track, rotor holder, compression tester, and others. While the third part is a coach seat.

\section{3) Participants Motivation}

Training participants were motivated during the training. This motivation was provided by a trainer in the form of support to complete the training activities properly, in order to improve their ability and immediately find a job.

\section{4) Learning Style of Training Participants}

This training was conducted through theoretical, before practice. Training activities started with 30\% theory and supported by $70 \%$ practice. Therefore, most learning styles used by trainees were kinesthetic learning style. Trainees 
were trained in various ways to repair a motorcycle, according to the theories that have been examined previously.

5) Habituate Training Participants to Write

Trainees were accustomed to make notes about some additional guidance provided by the trainer during theory presentation. This guide provides an explanation of the module provided.

6) Habituate Participants in Reading Practice Guidelines

Training participants were generally provided with modules that examine technical guidelines for training implementation, especially practice. So, before practice, trainees were getting used to read the module to support the implementation process.

7) The Training Participants Ability in Solving Problems during Practice

Participants were generally able to solve problems encountered during practice. They possess complementary solutions among participants in a group. This cooperation is very beneficial, since participants may learn from each other that have the same goals for group achievement

Based on the description about quantum learning model application above, it can be concluded that the trainees were presented with practice and supported by the theory before the practice. In general, instructors provide theories in the form of introduction or description about benefits, and method to practice. Provided learning modules and classrooms were accompanied by teaching equipment to deliver theory. This classroom is united with a practice place, so models or supporting media to convey learning theory are sufficient.

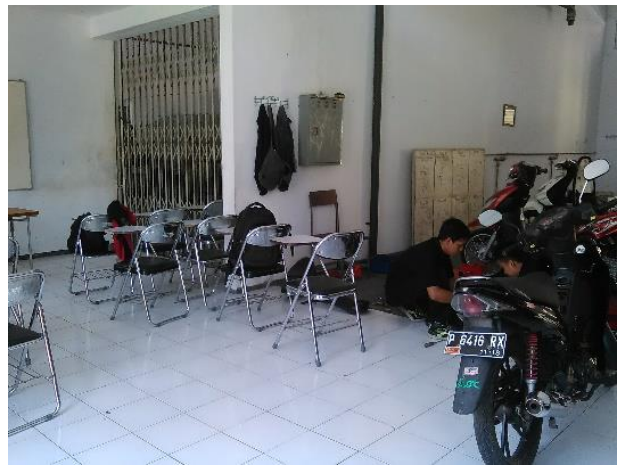

Fig. 1. Classroom and practice place.

During the process of delivering theory, participants emphasized in theoretical understanding activities, practice is performed afterwards. During practice, participants had three pieces of practical media in the form of motor units.

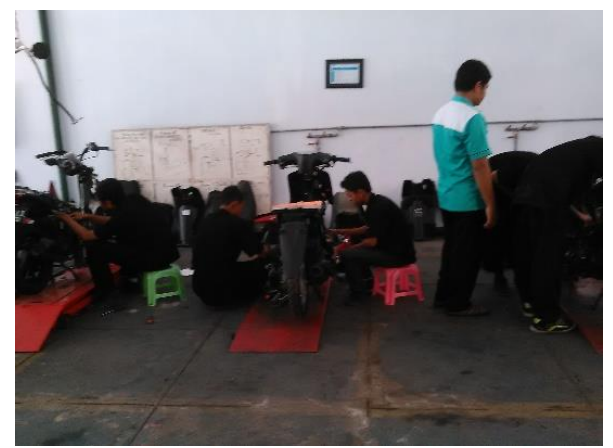

Fig. 2. Practical media.
All participants engaged, practical media to practice a theory that they had learned previously.

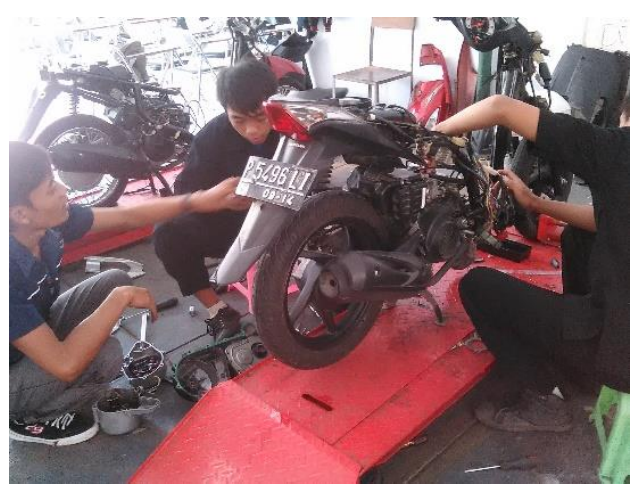

Fig. 3. Participats practice activity in a group.

They divided randomly into three small groups with composition of participants in various backgrounds. The results of research of online game community show that the social tolerance of community members increases due to the heterogeneity of members within the community [15]. This practice was expecting participants to be able to support each other, and nurture the idea of tolerance among peers. During this practice activity, participants can fully develop their abilities without instructor guidance, hence participants can be more independent in determining the proper solution toward an issue that may arise. Since, the result of research shows that providing assistance only if it is really necessary in learning will train someone to be independent [16].

Based on data collection results through questionnaires, indicated most participants stated that they had a positive motivation in carrying out training activities. Participants said that training activity is beneficial for them. In addition, the explanation given by the instructor prior to the practice encourages participants to be more easily understand the material. Moreover, supported by the media, a study room and a comfortable practice helps participants more enthusiast for learning activities. It can be concluded that quantum learning model in vocational training sub motorcycle Automotive has been running well. This successful implementation of quantum learning model affects tolerance and independence enhancement of trainees.

\section{A. Training Participants Tolerance}

Based on the data collected results through questionnaires also note that there was a positive, significant and very high correlation, between quantum learning model with a tolerance of trainees. This proved by the calculation of price $r$ of 0.708 in $95 \%$ confidence level. The value of $r$ count can be interpreted through the following table [17]:

TABLE II: THE INTERPRETATION VALUES $R_{\text {COUNT }}$

\begin{tabular}{ll}
\hline \hline The value of $\mathrm{r}$ & Information \\
\hline Very high & Figures 0.800 to 1.00 \\
High & Figures 0.600 to 0.790 \\
Enough & Figures 0.400 to 0.590 \\
Low & Figures 0.200 to 0.390 \\
Very low & Figures 0,000 to 0.190 \\
\hline \hline
\end{tabular}

Based on Table II: Interpretation Value of $\mathrm{r}$ count, can be determined the correlation between quantum learning model with tolerance if it is interpreted in line to both $r$ count value 
which is 0.708 stands between the values of 0.600 to 0.790 , hence it is classified as posing a high influence. In the form of relationship percentage between quantum learning model and trainee's tolerance is $50 \%$. It showed that quantum learning model in UPT-PK Jember, Indonesia has shown to obtain a high correlation tolerance and contribute to automotive training participants by $50 \%$.

Those contributions can be seen from several aspects, namely:

1) Participants admitted more familiar to each other. They often establish good communication through habitual practices. Being acquainted with each other, and more frequent interactions encourage participants to be closer.

2) They obtain better ability to appreciate other people's opinions encouraged by groups formed during the process of practice. Activities in the group make them accustomed to accept different opinions among group members, in solving problems that arise on a motorcycle during the practice.

3) Participants should feel supported by learning process of a group, since there are ability differences to understand the learning material, they are inevitably to learn in order to achieve the group's goals

4) This study process also establishes good habits within the participants. They are not reluctant to help other trainees who have difficulty outside the training activities. So, there is a sense of brotherhood among trainees.

5) The important thing is awakening tolerance among participants of the majority religion of Islam. This is given that the issue of lack of tolerance among religious communities in Indonesia. Several cases have plagued Muslims as well as action 212 in Jakarta, leading to another action to protest the harassment of the holy book of Islam by one of the politicians. This immediately became the conversation of the people of Indonesia who are non-Muslim. They have question about the Muslims' tolerance of human beings. The results of this study, just be an example that the tolerance of Muslims is high regarding matters of mutual respect and appreciate the opinions of others. The trainees even communicate with each other well with colleagues. The familiarity establishes a mutually beneficial relationship among the trainees to achieve the learning target. It can be concluded that those who are Muslim have tolerance in respecting the opinions of others, just not accepting any form of abuse against their religion. So, the realm of fighting for his religion is the main point that is held firmly.

The contribution above show the suitability between the results of research and existing theories, that tolerance can be improved through the process of teaching in a group with participants of different background [13], [15], [18]. Thus, quantum learning is an appropriate model as a solution to increase tolerance. Participants obtained comfort sense in learning, communication and good cooperation among training participants.

\section{B. Training Participants Independence}

Based on the questionnaire that has been distributed to all participants, there is also a positive, significant and very high, between quantum learning model with the independence of the trainees. The results of calculation of $r$ equal to 0.746 in the $95 \%$ confidence level. The count $r$ value can be interpreted refer to Table II: Interpretation of $r$ count value [17] can recognize the relationship between the quantum model of learning and independence that stands between values of 0.600 to 0.790 or high impact. In the form of relationship percentage between quantum models of learning and independence is $56 \%$. This indicates that quantum learning model in UPT-PK Jember, Indonesia is proved to gain high relationship and contribution toward the independence rate of automotive training participants that is $56 \%$.

Those contributions are explained further as follows:

1) Training participants were able to determine their own desires, especially in term of learning interests. This was proved by the existing system of specialization prior to the training. Hence, participants did not find any form of coercion in determining interest in learning. They take vocational automotive sub is based on their respective interests.

2) During training activities engaged quantum learning model, participants were provided with the opportunity to recognize the limits of their own abilities in a group practice. Thus, trainees in groups were able to determine learning material that's already been learned or not.

3) Application of quantum learning model also enhances participants enable to generate decisions better based on their own or little help.

4) Trainees became more skilled in addressing the issue of learning itself. In this sense, participants have been able to think about the appropriate action to resolve the problems, either by relying on the understanding that has been obtained in the theory submitted by the instructors previously, or to look further by learning in fellows group

5) Participants became tough and persistent

The contribution above indicates the suitability between the results of research and existing theories, independent individual is able to generate action in planning, implementing and evaluating the learning process, including learning objectives [19], [20]. Thereby, quantum learning can be a solution to increase independence. This encourages trainees to be more enjoyed in practice and explore their skill without relying on the trainer.

\section{CONCLUSION}

There was a positive significant relationship and was very intense, between quantum learning model towards tolerance and self-learning by participants. Thus, the quantum learning model is the accomplishment to incline tolerance and independence rate of trainees. If it is implemented properly, associated to the implementation and application of automotive vocational training activities in UPT motorcycle-PK Jember, Indonesia, then quantum learning model suits to stimulate individual tolerance and independence.

\section{REFERENCES}


[1] Y. Muhammad, "Makna toleransi dalam al-qur'an," Jurnal Ushuluddin, vol. 22, no. 2, pp. 170-180, July 2014.

[2] Saptono, "Dimensi-dimensi Pendidikan Karakter: Wawasan, Strategi, dan Langkah Praktis," Jakarta: Esensi Erlangga Group, 2011.

[3] S. Miller and O. S. David, "Stability and change in social tolerance: A test of the persistence hypothesis," American Journal of Political Science, vol. 30, no. 1, pp. 214-236, 1986.

[4] A. Iis, "Urgensi implementasi pendidikan multikultural di sekolah," Jurnal Pemikiran Alternatif Pendidikan," vol. 12, no. 2, pp. 220-233, August 2007.

[5] Churchill, F. Tan et al., "Craniofacial feminization, social tolerance, and the origins of behavioral modernity," The University of Chicago Press on behalf of Wenner-Gren Foundation for Anthropological Research, vol. 55, no. 4, pp. 419-443.

[6] Tomasello and Michael, Why We Cooperate, Cambridge, MA: MIT Press, pp. 43-107, 2009.

[7] B. B. Wolman, "Dictionary of behavioral science," New York: Van Nostrand Reinhold Company, 1973.

[8] A. Ida, "Pengaruh kemandirian belajar dan disiplin belajar terhadap prestasi belajar siklus akuntansi siswa kelas x Smk Negeri 7 Yogyakarta tahun ajaran 2007/2008," Thesis, Yogyakarta: UNY Press, 2008.

[9] A. R. Hasanah, "Hubungan antara kemandirian dengan penyesuaian diri pada siswa pondok pesantren. Naskah publikasi hasil penelitian," Thesis, Dept. Psychology, Muhammadiyah Surakarta University, 2012.

[10] T. Alex and N. J. Raihani, "The evolution of teaching. Animal behavior," vol. 75, no. 6, pp. 1823-1836, 2008.

[11] Buckley \& Caple, "The theory and practice of training," London Kogan Page, 2007, p. 5.

[12] Prihatiningsih, "Peningkatan Kompetensi Siswa SMK Hamong Putera 2 PAKEM Pada Pendeskripsian Parameter Operasional (Program) Pengoperasian Unit Generator Pembangkit Berbasis PLC Dengan Model Pembelajaran Quantum Learning," Fakultas Teknik Universitas Negeri Yogyakarta, vol. 5, no. 1, pp. 18-26, 2015.

[13] Suryana, 'Improvement of students' history learning competence through quantum learning model at senior high school in karanganya regency, solo, Central Java Province, Indonesia," Journal of Education and Practice, vol. 4, no. 14, pp. 55-63, 2013.
[14] DePorter and Hernacki, "Quantum learning: Membiasakan belajar nyaman dan menyenangkan," Bandung: Kaifa, PT. Mizan Pustaka, 2013.

[15] K. Tetsuro, "Bridging social capital in online communities: Heterogeneity and social tolerance of online game players in Japan", Human Communication Research, vol. 36, no. 4, pp. 546-569, October 2010.

[16] L. Martha, "Providing support for student independence through scaffolded instruction. Council for exceptional children," vol. 34, no. 1 , pp. 30-34, September/October 2001.

[17] M. Sulthon, "Metode penelitian pendidikan," Jember: Lembaga Pengembangan Manajemen Dan Profesi Keperndidikan, 2010.

[18] T. Claudio, J. Call, and M. Tomasello, "Ratcheting up the ratchet: On the evolution of cumulative culture," Philosophical Transactions of the Royal Society B: Biological Sciences, vol. 364, no. 1528, pp. 2405-2415, August 2009.

[19] Merriam, Caffarella \& Baumgartner, "Learning in adulthood: A comprehensive guide," San Francisco: Jossey Bass, 2017, pp. 1-329.

[20] D. W. Mocker and G. E. Spear, "Lifelong learning: Formal, Non-formal, informal and self-directed," Columbus, Ohio: ERIC, 1982, pp. 5-23.

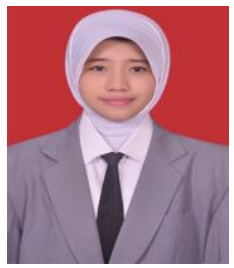

Lusy Setiyowati was born in Bojonegoro, East Java Indonesia on August 18, 1993. She is the candidate for the master degree in major nonformal education, Faculty of Education at Universitas Pendidikan Indonesia, 229th Dr. Setiabudi Street, Bandung, Indonesia. She got the alumnus of bachelor degree in major nonformal education at Jember University, Indonesia.

She has previously published about the ability of mathematical literacy of adults who have not received formal education. It is presented in mathematics education seminar at State University of Malang, April 8, 2017.

Setiyowati, S.Pd. is the first author and member of the Matagaruda LPDP Awardee since 2016. Dr. Saripah, S.Pd, M.Pd, is the co-author and a lecturer at Indonesia University of Education in major Nonformal Education, Faculty of Education. 